\title{
Feeding habits of six anuran (Amphibia: Anura) species in a rainforest fragment in Northeastern Brazil
}

\author{
Ednilza M. Santos ${ }^{1}$; Argus V. Almeida² \& Simão D. Vasconcelos ${ }^{3}$
}

1. Mestrado em Biologia Animal, Departamento de Zoologia, Universidade Federal de Pernambuco.
2. Departamento de Biologia, Universidade Federal Rural de Pernambuco, R. Dom Manoel de Medeiros, s/n ${ }^{\circ}, 52171-900$ Recife, PE,
Brasil.
3. Departamento de Zoologia, Centro de Ciências Biológicas, Universidade Federal de Pernambuco, Av. Prof. Moraes Rego, s/n ${ }^{\circ}$,
50670-420 Recife, PE, Brasil. (simao@ufpe.br)

\begin{abstract}
Although Brazil encompasses one of the most abundant anuran faunas in the world, quantitative information on anuran ecology and diet are limited, especially in the Northeastern region. We analyzed the diet of six species: Hyla albomarginata, Hyla ef. branneri, Hyla minuta, Phyllomedusa aff. hypochondrialis (Hylidae), Leptodactylus natalensis, and Physalaemus cuvieri (Leptodactylidae) in a temporary pond in a rainforest remnant in Pernambuco, between 19992000. We analyzed diet composition, degree of food preference, and seasonal variations in diet. Leptodactylus natalensis and P. cuvieri showed higher diet diversity, whereas H. minuta consumed fewer food items. Insecta, Arachnida, and plants were preferential items for most species. Acari were consumed by all species; Hymenoptera, Odonata, and Coleoptera were also often consumed. A slight increase in diet diversity occurred in the rainy season. The species showed a generalist feeding behaviour, although $P$. cuvieri consumed Formicidae as major prey item.
\end{abstract}

KEYWORDS. Hylidae, Leptodactylidae, diet, frogs, Pernambuco.

\section{INTRODUCTION}

Anurans are traditionally described as generalist predators, with opportunistic foraging behaviour. The main items in adult diet consist of invertebrates, including molluscs, annelids, centipedes, millipedes, arachnids, crustaceans and, especially, insects (TOFт, 1980a, 1981; Duellman \& Trueb, 1986; Piñero \& La Marca, 1996; Lima \& Magnusson, 1998; Van SLuYs \& Rocha, 1998; ANDERSON et al., 1999). Small vertebrates, such as fish, rodents, birds, and frogs, may occasionally be consumed by larger frogs (Duellman \& Trueb, 1986) and cannibalism may also occur (CRUMP, 1992). Recent studies have suggested that many species show some degree of diet specialization (Simon \& ToFt, 1991; Tоғт, 1995) whereas others can feed on a variety of "non-orthodox" items. For example, herbivory may be a relatively common behaviour in some species, such as Xenohyla truncata (Izecksohn, 1959), which feeds on fruits for a significant part of its adult stage (SiLva et al., 1989).

TOFт (1980a, 1981) identified two main diet patterns in tropical anurans: the "ant specialists" that eat more chitinous, slow-moving arthropods such as ants and mites; and the "non-ant specialists" that eat larger, less chitinous and more mobile arthropods, such as orthopterans and large spiders. These diet specializations are intrinsically linked to foraging strategies (sit-and-wait or active searching behaviour), nocturnal or diurnal activity patterns, the nature of defense mechanisms (camouflage, escape or poison) (ToFT, 1985; Duellman \& Trueb, 1986; Lima \& Magnusson, 1998), the type of habitat occupied, and the seasonal variability in resource abundance (ToFt, 1980a, 1981; Duellman \& Trueb, 1986; MOREIRA \& BARRETO, 1996).

Dietary information is crucial for the understanding of anuran life history, population fluctuations, and the impact of habitat modification on those populations
(ANDERSOn et al., 1999). This is particularly true for species that inhabit endangered areas, such as the Brazilian Atlantic rainforest, which nowadays makes up to only $8 \%$ of its original area (CONSERVATION InTERnaCional Do Brasil, 2000). Although Brazil encompasses one of the most diverse anuran faunas in the world, studies on the feeding habits of native anuran species are scarce. The few available data focus mainly on species from the Southeastern or the Amazonian region, so that little is known about the species composition, behaviour, and feeding habits of anurans in the Northeastern region of the country, where remnants of rainforest are the habitat for an increasingly endangered anuran fauna.

As part of a study on anuran ecology in a rainforest remnant in Northeastern Brazil, we studied the diet composition of six species, with emphasis on insects and arachnids as prey items. Specifically, we observed: i) the identification of the main prey items consumed; ii) the seasonal differences in diet composition; and iii) the degree of preference for particular food groups.

\section{MATERIAL AND METHODS}

Description of the area. This study was carried out in a temporary pond located at the Tapacurá Ecological Station $\left(09^{\circ} 07^{\prime} \mathrm{S}, 34^{\circ} 60^{\prime} \mathrm{W}\right)$, State of Pernambuco, Northeastern Brazil. This conservation unit has 776 ha and is located at an altitude of about $208 \mathrm{~m}$. It has a mean annual temperature of $26^{\circ} \mathrm{C}$ and $80 \%$ relative humidity. Average monthly rainfall during the study varied from $50 \mathrm{~mm}$ (Nov-Dec) to $670 \mathrm{~mm}$ (June-July), with a rainy season between April and September (FIDEM, 1987). The pond is maintained mainly by rainfall and by the water originating from the periodic flooding of a small lake located $c a .150 \mathrm{~m}$ away.

A semi-deciduous rainforest with some points of degradation surrounds the pond. The abundant and 
diverse vegetation includes trees (Anacardiaceae, Caesalpiniaceae, Mirtaceae, Mimosaceae, Rubiaceae, and Sapindaceae), shrubs (Lytraceae, Malvaceae, Melastomataceae, and Solanaceae) and herbs. The latter include terrestrial plants (Acanthaceae, Commelinaceae, Cucurbitaceae, Cyperaceae, and Poaceae) located around the pond, and aquatic plants (Araceae, Pteridaceae, and Laminaceae) scattered throughout the pond.

Animal capture. We studied six species, which were relatively abundant in the area: Hyla albomarginata Spix, 1824, Hyla minuta Peters, 1872, Hyla cf. branneri Cochran, 1924, Phyllomedusa aff. hypochondrialis (Daudin, 1801) (Hylidae), Leptodactylus natalensis Lutz, 1930, and Physalaemus cuvieri (Fitzinger, 1825) ( Leptodactylidae). All the frogs in the pond were collected manually from $20 \mathrm{~h}$ to $22 \mathrm{~h}$ in both dry (October-November/1999) and wet season (June-July/2000), with four contiguous sampling days per season. The pond surroundings ( $3 \mathrm{~m}$ away from the edge) were also included in the sampling area. During collection, information on the location, substrate, and activity of each animal was registered. We measured the snout-vent length of each animal using a caliper rule to the nearest $0.1 \mathrm{~mm}$. Animals were killed as painless as possible, using chlorobutanol. To conserve the gut contents, animals were then transferred individually to glass vials containing $10 \%$ formalin and kept in $70 \%$ alcohol thereafter. Voucher specimens of all species were deposited at the Vertebrate Collection at the Department of Zoology of the Universidade Federal de Pernambuco, Brazil.

Analysis of stomach contents. In the laboratory, frog stomachs were removed and the contents were analyzed under a stereoscopic microscope. Food was initially categorized in large groups, mainly phylum and class. We analyzed the diet using two parameters: the frequency of occurrence of different food groups, and the degree of food "preference" for each prey item. The frequency of occurrence was defined as the percentage of stomachs of each frog species containing a particular type of food. A food group was then classified as constant when registered in $>50 \%$ of the stomachs of a particular species, secondary when present in $25-50 \%$ of stomachs, or accidental when observed in $<25 \%$ of the stomachs (DAJOZ, 1983).

To infer about the consumption for a particular food group, we used the Degree of Food Preference (DFP), index developed by Braga (1999). We used the term "preference" here to designate major differences in food comsumption, although prey availability was not addressed for logistical reasons. Food was ranked by categories from 1 to 4 , in the following way: the maximum value (4) was assigned when only one food group was found in a stomach. When stomachs contained more than one group, the value " 3 " was given to the most abundant, while " 2 " was given to the second most common, and " 1 " was attributed to less abundant groups. Abundance here was estimated by the number of prey items of each category in each stomach. DFP was calculated as: $D F P=S(i) / N$; where $S(i)$ is the sum of values given to a food group $i$ in the guts, and $N$, the total number of guts of each species analyzed. Food groups were then categorized as highly preferential $(3<$ DFP $<4)$, preferential $(2<\mathrm{DFP}<3)$, secondary $(1<\mathrm{DFP}$ $<2$ ) or occasional $(0<\mathrm{DFP}<1)$.

\section{RESULTS}

From 128 animals captured, 122 had stomach contents, and were used in the analysis (tab. I). The food consumed was categorized in 10 groups: mineral, plant, Mollusca, Annelida, Arachnida, Insecta, Diplopoda, Chilopoda, Crustacea, and Amphibia. All inorganic matter was grouped as mineral and included among the food items, although not traditionally ranked as such. A further category consisted of unidentified fragments (mostly invertebrates), which were not included in the analysis.

Diet composition varied among the six species analyzed. Hyla minuta consumed a limited number of food groups ( 2 in the dry and 4 in the wet season), compared to the more diverse diet of $L$. natalensis ( 8 and 9 groups in the dry and wet season, respectively) (tab. II). Three items, Insecta, Arachnida and plant, were the most frequent contents in the stomachs of all species, in both seasons. Plant and Insecta, in particular, were consistently observed items in most samples. Inorganic material (mineral) was registered in most species, especially in the wet season. The least consumed food groups throughout the study were Annelida, Mollusca, Chilopoda, and Diplopoda, all of which were eaten by only one species, L. natalensis. Eggs and larvae of Amphibia were the only vertebrate prey item detected, and were observed only in the stomachs of $L$. natalensis.

Table I. Species of anurans collected in a temporary pond at the Tapacurá Ecological Station, Pernambuco, Brazil, between 19992000, used for diet analysis (X, mean; SD, standard deviation).

\begin{tabular}{|c|c|c|c|c|}
\hline \multirow{2}{*}{ S P E C I E S } & \multirow{2}{*}{$\begin{array}{l}\text { Snout-vent length } \\
(\mathrm{mm}) \\
\mathrm{X} \pm \mathrm{SD}\end{array}$} & \multirow[t]{2}{*}{ HABITAT } & \multicolumn{2}{|c|}{ Number of adults analyzed } \\
\hline & & & $\begin{array}{l}\text { DRY SEASON } \\
\text { Nov-Dec/1999 }\end{array}$ & $\begin{array}{l}\text { WET SEASON } \\
\text { June-July/2000 }\end{array}$ \\
\hline \multicolumn{5}{|l|}{ Family Hylidae } \\
\hline Hyla albomarginata & $50.1 \pm 3.82$ & Trees, shrubs & 07 & 15 \\
\hline Hyla cf. branneri & $17.5 \pm 2.16$ & Terrestrial and semi-aquatic shrubs & 18 & 10 \\
\hline Hyla minuta & $22.5 \pm 0.93$ & Terrestrial and aquatic shrubs & 02 & 16 \\
\hline Phyllomedusa aff. hypochondrialis & $31.0 \pm 9.38$ & Shrubs, herbs & 13 & 13 \\
\hline \multicolumn{5}{|l|}{ Family Leptodactylidae } \\
\hline Leptodactylus natalensis & $40.6 \pm 4.28$ & Soil, shrubs, under vegetation & 05 & 09 \\
\hline Physalaemus cuvieri & $27.1 \pm 2.53$ & Soil, shrubs, under vegetation & 02 & 12 \\
\hline T O T A L & & & 47 & 75 \\
\hline
\end{tabular}


Regarding the Degree of Food Preference, most items were considered occasional or secondary (tab. III). Insecta was preferential for some species, especially $P$. cuvieri in the dry season, when it was a highly preferential food group (DFP $=3.00)$. For most species, plant and Arachnida were the second and third most preferred food groups respectively. We observed slight differences in diet composition of most species according to the season, with a small increase in the number of food groups consumed in the wet season, especially for $H$. albomarginata and $P$. cuvieri (tab. II).

The consumption of insects and arachnids varied among the species and between the seasons (tabs. IV, V). A higher diversity of items was eaten by Phyllomedusa aff. hypochondrialis in both seasons, whereas Physalaemus cuvieri seemed to feed on a narrower range of insects and arachnids. Among the insects, a high consumption of Hymenoptera (mostly ants) was observed throughout the study, whereas orders such as Lepidoptera and Diptera were little consumed. Mites were the only prey item common to all species, although ants, beetles and spiders were eaten by most species. Ants were observed in all P. cuvieri stomachs analyzed, in both seasons (tabs. IV, V).

\section{DISCUSSION}

Hyla albomarginata, $H$. cf. branneri, $H$. minuta, Phyllomedusa aff. hypochondrialis, Leptodactylus natalensis, and Physalaemus cuvieri were shown to have a wide diet diversity in terms of phylum (at least six for most species), habitat (soil, plants, water), and even part of the plant ingested (leaf, fruit, seed, pollen, bark, etc.). They consumed invertebrate prey with remarkable differences in size (from collembolans to dragonflies), rigidity (from hard-shelled crustaceans to soft-bodied annelids), behaviour (cryptic or conspicuous; slowmoving or highly mobile insects), and developmental stage (egg, young, and adult).

Such differences in prey items suggest differences in habitat occupation, which is the case of $H$. albomarginata. Despite being visualized mostly on trees and shrubs during field collection (tab. I), the adults probably dwell not only in vegetation but also in water (since aquatic snails were identified) and soil, given the consumption of terrestrial centipedes. Therefore, data on diet composition can support ecological and behavioural field studies.

Terrestrial and aquatic insects have been reported as preferential anuran prey items in several studies conducted over the past 20 years (ToFt, 1980a, 1981; Piñero \& La Marca, 1996; VAn Sluys \& Rocha, 1998; Anderson et al., 1999; Cogalniceanu et al., 2001). From the insect orders identified as prey items in this study, Odonata, Coleoptera, and Hymenoptera were eaten by almost all species. Other arthropods, such as Acari and Araneae, were also frequently consumed. Since a number

Table II. Frequency of occurrence (\%) of food groups registered in the stomach of anurans collected at the Tapacurá Ecological Station, Brazil, in the dry season (Oct-Nov/1999) and wet season (June-July/2000). Food groups were classified as constant (c), secondary (s), or accidental (a) (Ha, Hyla albomarginata; Hb, Hyla cf. branneri; Hm, Hyla minuta; Ph, Phyllomedusa aff. hypochondrialis; Ln, Leptodactylus natalensis; Pc, Physalaemus cuvieri).

\begin{tabular}{|c|c|c|c|c|c|c|c|c|c|c|c|c|}
\hline & \multicolumn{2}{|c|}{$\mathrm{Ha}$} & \multicolumn{2}{|c|}{$\mathrm{Hb}$} & \multicolumn{2}{|c|}{$\mathrm{Hm}$} & \multicolumn{2}{|c|}{$\mathrm{Ph}$} & \multicolumn{2}{|c|}{$\mathrm{Ln}$} & \multicolumn{2}{|c|}{$\mathrm{Pc}$} \\
\hline & dry & wet & dry & wet & dry & wet & dry & wet & dry & wet & dry & wet \\
\hline Mineral & & $6.7^{\mathrm{a}}$ & $22.2^{\mathrm{a}}$ & $40.0^{\mathrm{s}}$ & & $25.0^{\mathrm{a}}$ & $7.7^{\mathrm{a}}$ & $38.5^{\mathrm{s}}$ & $100^{\mathrm{c}}$ & $55.5^{\mathrm{c}}$ & $100^{\mathrm{c}}$ & $100^{\mathrm{c}}$ \\
\hline Plant & $100^{\mathrm{c}}$ & $80.0^{\mathrm{c}}$ & $55.6^{\mathrm{c}}$ & $30.0^{\mathrm{s}}$ & $100^{\mathrm{c}}$ & $37.5^{\mathrm{s}}$ & $53.8^{c}$ & $100^{\mathrm{c}}$ & $100^{\mathrm{c}}$ & $55.5^{\mathrm{c}}$ & $100^{\mathrm{c}}$ & $91.7^{\circ}$ \\
\hline Mollusca & & $6.7^{\mathrm{a}}$ & & & & & & & $20.0^{\mathrm{a}}$ & $22.2^{\mathrm{a}}$ & & $8.3^{\mathrm{a}}$ \\
\hline Annelida & & & & & & & & & & $11.1^{\mathrm{a}}$ & & $8.3^{\mathrm{a}}$ \\
\hline Arachnida & $100^{\mathrm{c}}$ & $40.0^{\mathrm{s}}$ & $22.2^{\mathrm{a}}$ & $20.0^{\mathrm{a}}$ & & $31.3^{\mathrm{s}}$ & $7.7^{\mathrm{a}}$ & $53.8^{\mathrm{c}}$ & $100^{\mathrm{c}}$ & $55.5^{\mathrm{c}}$ & $100^{\mathrm{c}}$ & $41.6^{\mathrm{s}}$ \\
\hline Crustacea & & & & & & & & & & $55.5^{c}$ & & \\
\hline Chilopoda & & $6.7^{\mathrm{a}}$ & & & & & & & $20.0^{\mathrm{a}}$ & & & $8.3^{\mathrm{a}}$ \\
\hline Diplopoda & & & & & & & & & $20.0^{\mathrm{a}}$ & $11.1^{\mathrm{a}}$ & & \\
\hline Insecta & $42.4^{s}$ & $86.7^{c}$ & $100^{\mathrm{c}}$ & $90.0^{c}$ & $100^{\mathrm{c}}$ & $43.8^{s}$ & $92.3^{c}$ & $69.2^{c}$ & $100^{\mathrm{c}}$ & $100^{c}$ & $100^{\mathrm{c}}$ & $100^{\mathrm{c}}$ \\
\hline Amphibia & & & & & & & & & $20.0^{\mathrm{a}}$ & $33.3^{\mathrm{s}}$ & & \\
\hline DTAL OF FOOD GROUPS & 3 & 6 & 4 & 4 & 2 & 4 & 4 & 4 & 8 & 9 & 4 & 6 \\
\hline
\end{tabular}

Table III. Degree of Food Preference (DFP) by anurans collected at the Tapacurá Ecological Station, Brazil, in the dry season (Oct-Nov/ 1999) and wet season (June-July/2000). Food groups were classified as highly preferential (hp), preferential (p), secondary (s), or occasional (o) (Ha, Hyla albomarginata; Hb, Hyla cf. branneri; Hm, Hyla minuta; Ph, Phyllomedusa aff. hypochondrialis; Ln, Leptodactylus natalensis; Pc, Physalaemus cuvieri).

\begin{tabular}{|c|c|c|c|c|c|c|c|c|c|c|c|c|}
\hline & \multicolumn{2}{|c|}{$\mathrm{Ha}$} & \multicolumn{2}{|c|}{$\mathrm{Hb}$} & \multicolumn{2}{|c|}{$\mathrm{Hm}$} & \multicolumn{2}{|c|}{$\mathrm{Ph}$} & \multicolumn{2}{|c|}{$\mathrm{Ln}$} & \multicolumn{2}{|c|}{$\mathrm{Pc}$} \\
\hline & dry & wet & dry & wet & dry & wet & dry & wet & dry & wet & dry & wet \\
\hline Mineral & & $0.06^{\circ}$ & $0.47^{\circ}$ & $0.90^{\circ}$ & & $0.81^{\circ}$ & $0.07^{\circ}$ & $0.16^{\circ}$ & $1.00^{\mathrm{s}}$ & $0.55^{\circ}$ & $0.50^{\circ}$ & $0.91^{\circ}$ \\
\hline Plant & $2.57^{p}$ & $1.13^{\mathrm{s}}$ & $0.44^{\circ}$ & $0.40^{\circ}$ & $1.00^{\mathrm{s}}$ & $1.06^{\mathrm{s}}$ & $1.57^{\mathrm{s}}$ & $2.30^{\mathrm{p}}$ & $0.80^{\circ}$ & $0.66^{\circ}$ & $0.50^{\circ}$ & $0.91^{\circ}$ \\
\hline Mollusca & & $0.20^{\circ}$ & & & & & & & $0.40^{\circ}$ & $0.33^{\circ}$ & & $0.33^{\circ}$ \\
\hline Annelida & & & & & & & & & & $0.20^{\circ}$ & & $0.08^{\circ}$ \\
\hline Arachnida & $1.70^{\mathrm{s}}$ & $0.93^{\circ}$ & $0.71^{\circ}$ & $0.60^{\circ}$ & & $1.60^{\mathrm{s}}$ & $1.10^{\mathrm{s}}$ & $0.76^{\circ}$ & $1.20^{\mathrm{s}}$ & $0.99_{\mathrm{s}}^{\circ}$ & $1.50^{\mathrm{s}}$ & $0.81^{\circ}$ \\
\hline Crustacea & & $026^{\circ}$ & & & & & & & $020^{\circ}$ & $1.00^{\mathrm{s}}$ & & $0<0^{\circ}$ \\
\hline $\begin{array}{l}\text { Chilopoda } \\
\text { Diplopoda }\end{array}$ & & 0.26 & & & & & & & $\begin{array}{l}0.20^{\circ} \\
0.20^{\circ}\end{array}$ & $0.66^{\circ}$ & & 0.80 \\
\hline $\begin{array}{l}\text { Insecta } \\
\text { Amphibia }\end{array}$ & $0.71^{\circ}$ & $1.80^{\mathrm{s}}$ & $2.94^{p}$ & $2.10^{p}$ & $2.50^{p}$ & $2.25^{\mathrm{p}}$ & $1.07^{\mathrm{s}}$ & $1.76^{\mathrm{s}}$ & $\begin{array}{l}1.00^{\mathrm{s}} \\
0.20^{\circ}\end{array}$ & $\begin{array}{l}1.77^{\mathrm{s}} \\
0.40^{\circ}\end{array}$ & $3.00^{\mathrm{hp}}$ & $2.66^{p}$ \\
\hline
\end{tabular}


Table IV. Frequency of occurrence (\%) of Arachnida and Insecta items eaten by anurans in the dry season (Nov-Dec/1999) at the Tapacurá Ecological Station, Brazil. Ha, Hyla albomarginata $(N=7)$; Hb, Hyla cf. branneri $(N=18) ; \mathrm{Hm}$, Hyla minuta $(N=2)$; Ph, Phyllomedusa aff. hypochondrialis $(N=13)$; Ln, Leptodactylus natalensis $(N=5)$; Pc, Physalaemus cuvieri $(N=2)$. Collembola was included among insects for the sake of clarity.

\begin{tabular}{|c|c|c|c|c|c|c|}
\hline \multirow[t]{2}{*}{ FOOD ITEMS } & \multicolumn{6}{|c|}{ S P E C I E S } \\
\hline & $\mathrm{Ha}$ & $\mathrm{Hb}$ & $\mathrm{Hm}$ & $\mathrm{Ph}$ & $\mathrm{Ln}$ & $\mathrm{Pc}$ \\
\hline \multicolumn{7}{|l|}{ ARACHNIDA } \\
\hline Acari: Oribatida & 28.6 & 22.2 & & 7.7 & 40.0 & \\
\hline Acari: unidentified & 28.6 & & & 46.2 & 40.0 & 100 \\
\hline Araneae: Araneidae & 28.6 & & & 15.4 & & \\
\hline Araneae: Phylodromidae & 14.3 & & & 15.4 & & \\
\hline Araneae: Salticidae & & & & 7.7 & 20.0 & \\
\hline Araneae: Tetragnathidae & & & & 15.4 & & \\
\hline Araneae: Theraphosidae & & & & 7.7 & & \\
\hline Araneae: unidentified & & 22.2 & & 7.7 & & \\
\hline \multicolumn{7}{|l|}{ INSECTA } \\
\hline Collembola & & 22.2 & 50.0 & & & \\
\hline Ephemeroptera: Ephemeridae & & 11.1 & & & & \\
\hline Odonata (naiads) & & 5.5 & & & 20.0 & \\
\hline Orthoptera: Gryllidae & 14.3 & & & & & \\
\hline Orthoptera: unidentified & 28.6 & 5.5 & & 7.7 & & \\
\hline Isoptera: Termitidae & & & & 15.4 & & 50.0 \\
\hline Embioptera: Embiidae & & & & 7.7 & & \\
\hline Hemiptera: Homoptera: Cicadellidae & & & 50.0 & 7.7 & & \\
\hline Hemiptera: Homoptera: unidentified & & 11.1 & & & & \\
\hline Coleoptera: Chrysomelidae & & 5.5 & & & & \\
\hline Coleoptera: Ptiliidae & & 5.5 & & & 20.0 & \\
\hline Coleoptera: Tenebrionidae & & 5.5 & 50.0 & & & \\
\hline Coleoptera: unidentified & & 5.5 & 50.0 & & 40.0 & \\
\hline Trichoptera (larvae) & & & & & & 50.0 \\
\hline Lepidoptera: Microlepidoptera & & 5.5 & & & & \\
\hline Diptera: Dolichopodidae & & & & 7.7 & & \\
\hline Diptera: Muscidae & & 5.5 & & & & \\
\hline Diptera: unidentified & & 38.9 & & 7.7 & & \\
\hline Hymenoptera: Formicidae & & 11.1 & & & 60.0 & 100 \\
\hline Hymenoptera: unidentified & & & & 7.7 & & \\
\hline
\end{tabular}

of prey items could not be identified, some insect orders may have been underestimated as food items. However, certain general trends can be observed. For example, $P$. cuvieri seems to fit into the category described by TofT (1980a) as "ant-specialist", given the high consumption of ants and termites by all individuals analyzed.

Curiously, plant items such as seeds, pieces of tree branches, leaves, and flowers were detected in almost all samples. Poaceae, in particular, were consumed by all species. Although the immediate explanation would imply accidental ingestion of vegetation while foraging for invertebrate preys, the idea that anurans may actually select plant resources as food items must be considered. According to ANDERSON et al. (1999), plant contents may help in the elimination of intestinal parasites, provide roughage to assist in grinding up arthropod exoskeletons, or provide nutrients and an additional source of water.

Information on plant consumption contributes to the understanding of behavioural patterns. The presence of anthers, stamens, pollen, seeds, and leaves in the stomachs indicates that vegetation is used not only as a reproductive site, but also as foraging territory. Reports on herbivory in tropical frogs have become more frequent in the past years. Silva et al. (1989) demonstrated that Xenohyla truncata includes bromeliad fruit and seeds in its diet, especially during the dry season, when invertebrates are less abundant. Plants can also constitute a significant part of the diet of adults of Rana hexadactyla (Lesson, 1834) (DAs, 1996). In the present study, plants were a constant food group for most species, with a moderate degree of preference compared to other food items, especially in the dry season.

The presence of anuran larvae and eggs in the stomach of $L$. natalensis observed here had not been previously reported. Although registered in other anuran species such as Nephelobates alboguttatus (Boulenger, 1903) (Piñero \& LA MARCA, 1996) and Rana sp. (WERnER et al., 1995), there is no report available on batracophagy among $L$. natalensis. Published information on the feeding habits of the six species studied here is scarce. VAn Sluys \& Rocha (1998) reported that spiders and hemipterans were the most frequent items consumed by H. minuta in Central Amazon. The present study adds Acari as another significant item in the $H$. minuta diet. MoreIra \& BARreto (1996) analyzed P. cuvieri feeding habits in the "cerrado" of Central Brazil and concluded that ants and termites were the preferential items, in agreement with the present study.

In general, the diversity of food groups increased only slightly in the wet season. Whether the greater diversity of items consumed in the wet season reflects an increase in the diversity and abundance of invertebrate prey in the area is still to be investigated. In Amazonian Peru, TofT (1980b) observed a decrease in arthropod biomass and in frog abundance in the dry season. However, she argued that frog species and their arthropod prey may respond differently to seasonal changes, since the principal feeding patterns of the litter anurans studied did not appear to change seasonally (TOFT, 1980b).

The diet similarity for most species may be 
Table V. Frequency of occurrence (\%) of Arachnida and Insecta items eaten by anurans in the wet season (June-July/2000) at the Tapacurá Ecological Station, Brazil. Ha, Hyla albomarginata $(N=15)$; Hb, Hyla cf. branneri $(N=10) ; \mathrm{Hm}$, Hyla minuta $(N=16) ; \mathrm{Ph}$, Phyllomedusa aff. hypocondrialis $(N=13)$; Ln, Leptodactylus natalensis $(N=9)$; Pc, Physalaemus cuvieri $(N=12)$. Collembola was included among insects for the sake of clarity.

\begin{tabular}{|c|c|c|c|c|c|c|}
\hline \multirow[t]{2}{*}{ FOOD ITEMS } & \multicolumn{6}{|c|}{$\mathrm{S} P \mathrm{P} E \mathrm{C} I \mathrm{E} S$} \\
\hline & $\mathrm{Ha}$ & $\mathrm{Hb}$ & $\mathrm{Hm}$ & $\mathrm{Ph}$ & $\mathrm{Ln}$ & $\mathrm{Pc}$ \\
\hline ARACHNIDA & & & & & & \\
\hline Acari: Oribatida & 26.7 & & 12.5 & 7.7 & 22.2 & 33.3 \\
\hline Acari: unidentified & 20.0 & 10.0 & 18.8 & 30.8 & 33.3 & 8.3 \\
\hline Araneae: Araneidae & & & & 15.4 & & \\
\hline Araneae: Phylodromidae & & & & 15.4 & & \\
\hline Araneae: Tetragnathidae & 13.3 & & & 7.7 & & \\
\hline Araneae: unidentified & 6.7 & 10.0 & & 15.4 & 22.2 & \\
\hline INSECTA & & & & & & \\
\hline Collembola & & 10.0 & & 15.5 & & \\
\hline Ephemeroptera: Ephemeridae & & 10.0 & & & & \\
\hline Odonata (naiads) & 6.7 & & 6.3 & & 33.3 & 8.3 \\
\hline Orthoptera: Gryllidae & 33.3 & & & 7.7 & & \\
\hline Orthoptera: Tettigoniidae & 6.7 & & & & & \\
\hline Orthoptera: unidentified & 33.3 & & & & & \\
\hline Blattodea: Blattidae & 6.7 & & & & 11.1 & \\
\hline Isoptera: Termitidae & & & & & & 41.7 \\
\hline Hemiptera: Heteroptera & & & & & 33.3 & \\
\hline Hemiptera:Homoptera: Cicadellidae & & & 6.3 & & & \\
\hline Hemiptera:Homoptera: Membracidae & 6.7 & & & & & \\
\hline Hemiptera:Homoptera: unidentified & & & 12.5 & 7.7 & & \\
\hline Coleoptera: Curculionidae & & & & 15.4 & 11.1 & \\
\hline Coleoptera: Chrysomelidae & & & 6.3 & & & \\
\hline Coleoptera: Tenebrionidae & & & 6.3 & & & \\
\hline Coleoptera: unidentified & 6.7 & 30.0 & 6.3 & 15.4 & 22.2 & \\
\hline Trichoptera (larvae) & & & & & & 8.3 \\
\hline Lepidoptera: Microlepidoptera & 6.7 & & & & & \\
\hline Diptera: Muscidae & & 10.0 & & & & \\
\hline Diptera: unidentified & & 10.0 & & & & \\
\hline Hymenoptera: Formicidae & & & 6.3 & 15.4 & 44.4 & 100 \\
\hline Hymenoptera: unidentified & & 10.0 & & 15.4 & & \\
\hline
\end{tabular}

consequence of the wide prey range and to the large food categories used in the analysis. There is evidence that competition for food can be avoided through differences between the microhabitat exploited, type of food consumed, and diel time of activity (Lima \& MAGNusson, 1998). In our study, microhabitat could only vary among some species at a small spatial scale, since they forage within a few meters from each other (tab. I). This, however, should not exclude some degree of spatial segregation, an important mechanism to reduce competition for resources, especially in periods of stress, such as during drought. Van SluYs \& Rocha (1998) reported that two syntopic frog species in the Amazon differed in their feeding habits due to their body size, microenvironment exploration, and activity time. We observed L. natalensis foraging during the day and in the evening, a behaviour that may have contributed to its widely diversified diet, with most food items classified as accidental or secondary, compared to other species. Also, for some community assemblages, seasonal division is a plausible mechanism to avoid competition because the majority of prey populations have short life cycles (Lima \& MAGNuSSON, 1998).

None of the parameters used here incorporated prey availability in the environment, a variable that was beyond the scope of this study. Resource availability is difficult to measure and has rarely been incorporated into anuran diet studies (but see ToFt, 1980b; Cogalniceanu et al., 2001). Recent studies have revealed that small vertebrate insectivores can be highly selective, discriminating actively among prey taxa (Simon \& Tofт, 1991; Tofт, 1995). Also, anurans can change their diet as they grow. The smallest arthropods available for anurans are mainly mites and collembolans; prey of intermediate size include ants, termites and beetles, whereas the largest arthropod items are orthopterans, lepidopterans and spiders (LiMA, 1998). The fact that mites are the most abundant terrestrial arthropods in soil and litter in tropical places (SimON \& Tofт, 1991) and that they are readily available for predators of any size can account for their ubiquity in the frog stomachs from this study.

This is, to our knowledge, the first report on feeding habits of anurans in rainforest fragments in Northeastern Brazil. Although the limited sampling period and number of individuals provide a preliminary estimation of the species' actual diet, we believe that a general feeding pattern has been found. The variables involved in an animal's diet are seldom obvious and include behavioural, physiological, and morphological features of both consumers and consumed (SimON \& TOFT, 1991). Therefore, data on diet determinants from locally endangered species, such as anurans from rainforest fragments, can be useful in the design of programmes on rainforest management and conservation.

Acknowledgments. To the managers of Estação Ecológica de Tapacurá - UFRPE, for the permission to develop fieldwork in the area; to Marcelo Peres and Magnolia Botelho for their invaluable help in identifying arthropods, and Catherine Toft, William Magnusson, and Trev Williams for helpful comments on the manuscript. This paper is part of 
the first author's M.Sc. dissertation, sponsored by a CNPq scholarship.

\section{REFERENCES}

Anderson, A. M.; Haukos, D. A. \& Anderson, J. T. 1999. Diet composition of three anurans from the Playa Wetlands of Northwest Texas. Copeia, Lawrence, 1999:515-520.

Braga, F. M. S. 1999. O grau de preferência alimentar: método qualitativo e quantitativo para o estudo do conteúdo estomacal de peixes. Acta Scientiarum, Maringá, 21:291295.

Cogalniceanu, D.; Palmer, M. W. \& Ciubuc, C. 2001. Feeding in anuran communities on islands in the Danube floodplain. Amphibia-Reptilia, Leiden, 22:1-19.

Conservation Internacional do Brasil. 2000. Avaliação e ações prioritárias para a conservação da biodiversidade da Mata Atlântica e Campos Sulinos. Brasília. Ministério do Meio Ambiente. 40p.

Crump, M. L. 1992. Cannibalism in amphibians. In: Elgar, M. A. \& Crespi, B. J. eds. Cannibalism: ecology and evolution among diverse taxa. Oxford, Oxford University. p. 256-276.

Dajoz, W. E. 1983. Ecologia Geral. São Paulo, Vozes. 474 p.

DAS, I. 1996. Folivory and seasonal changes in diet in Rana hexadactyla (Anura, Ranidae). Journal of Zoology, London, 238:785-794.

Duellman, W. E. \& Trueb, L. 1986. The Biology of Amphibians. New York, McGraw-Hill. 670 p.

Fidem (Fundação de Desenvolvimento da Região Metropolitana Do Recife). 1987. Reservas Ecológicas. Recife, FIDEM. 78 p. (Série de Desenvolvimento Urbano e Meio Ambiente).

Lima, A. P. 1998. The effects of size on the diets of six sympatric species of postmetamorphic litter anurans in Central Amazonia. Journal of Herpetology, Athens, 32:392-399.

Lima, A. P. \& Magnusson, W. E. 1998. Partitioning seasonal time: interactions among size, foraging activity and diet in leaf-litter frogs. Oecologia, Berlin, 116:259-266.

Moreira, G. \& BARReto, L. 1996. Alimentação e variação sazonal na freqüência de captura de anuros em duas localidades do Brasil Central. Revista Brasileira de Zoologia, Curitiba, 13:313-320

Piñero, J. \& La Marca, E. 1996. Hábitos alimentarios de Nephelobates alboguttatus (Anura: Dendrobatidae) en una selva nublada andina de Venezuela. Revista de Biologia Tropical, San José, 44:827-833.

Silva, H. R.; Britto-Pereira, M. C. \& Caramaschi, U. 1989. Frugivory and seed dispersal by Hyla truncata, a Neotropical tree-frog. Copeia, Lawrence, 1989:785-794.

Simon, M. P. \& Toft, C. A. 1991. Diet specialization in small vertebrates: mite-eating in frogs. Oikos, Stockholm, 61:263278

Tоғт, C. A. 1980a. Feeding ecology of thirteen syntopic species of anurans in a seasonal tropical environment. Oecologia, Berlin, 45:131-141.

1980b. Seasonal variation in populations of Panamanian litter frogs and their prey: a comparison of wetter and drier sites. Oecologia, Berlin, 47:34-38.

1981. Feeding ecology of Panamanian litter anurans: patterns in diet and foraging mode. Journal of Herpetology, Athens, 15:139-144.

1985. Resource partitioning in amphibians and reptiles Copeia, Lawrence, 1985:1-21.

1995. Evolution of diet specialization in poison-dart frogs (Dendrobatidae). Herpetologica, Chicago, 51:202-216.

Van Sluys, M. \& Rocha, C. F. D. 1998. Feeding habits and microhabitat utilization by two syntopic Brazilian Amazonian frogs (Hyla minuta and Pseudopaludicola sp. (gr. falcipes). Revista Brasileira de Biologia, São Carlos, 58:559-562.

Werner, E. E.; Wellborn, G. A. \& McPeek, M. A. 1995. Diet composition in postmetamorphic bullfrogs and green frogs implications for interspecific predation and competition. Journal of Herpetology, Athens, 29:600-607. 